\title{
Comparative cytotoxicity of purified Shiga-like toxin-Ile on porcine and bovine aortic endothelial and human colonic adenocarcinoma cells
}

\author{
A. VALDIVIESO-GARCIA, D. L. MACLEOD*, R. C. CLARKE, C. L. GYLES*, C. LINGWOOD*, \\ BETH BOYD ${ }^{\ddagger}$ and A. DURETTE
}

Health of Animals Laboratory, Agriculture and Agri-Food Canada, 110 Stone Road West, Guelph, Ontario N1G 3W4, *Department of Veterinary Microbiology and Immunology, Ontario Veterinary College, University of Guelph, Guelph, Ontario N1G 2W1 and ${ }^{\ddagger}$ Departments of Bacteriology and Biochemistry, The Hospital for Sick Children, 555 University Avenue, Toronto, Ontario M5G 1X8, Canada

\begin{abstract}
Porcine and bovine aortic endothelial cells and human colonic adenocarcinoma cells were compared for their susceptibility to the toxic effect of purified Shiga-like toxin IIe (SLT-IIe), measured by the neutral red cytotoxicity assay. Cytotoxicity correlated with toxin binding as indicated by fluorescence activated cell sorter analysis and with the globotriosylceramide $\left(G_{3}\right)$ and globotetraosylceramide $\left(G b_{4}\right)$ content of cells determined by high pressure liquid chromatography. One line of porcine aortic endothelial cells was 1400-fold more susceptible than the line of bovine aortic endothelial cells that was tested, but a second line of porcine aortic endothelial cells was highly refractory to SLT-IIe. Human colonic adenocarcinoma cells lacked detectable levels of $\mathbf{G b}_{4}$ and were least susceptible to SLT-IIe.
\end{abstract}

\section{Introduction}

The association of certain strains of verocytotoxigenic Escherichia coli (VTEC) with diseases in man and animals has generated much interest in the verocytotoxins (VTs) or Shiga-like toxins (SLTs). This family of toxins has been divided into two groups on the basis of neutralisation with specific antisera, nucleotide and amino-acid sequence, and cytotoxicity for Vero and HeLa cells [1-4]. SLT-I comprises one group and SLTII and its variants constitute the second group. SLT-IIe or VT2e (previously SLT-IIV) is a variant of SLT-II and is implicated in oedema disease of pigs. Clinical manifestations of inappetence, oedema of the eyelids and forehead, stupor and ataxia are associated with vascular damage in subcutaneous tissues and the brain. VTEC strains implicated in disease in man produce SLT-I or SLT-II, or both, and are associated with haemorrhagic colitis and the haemolytic uraemic syndrome. The variations in the clinical syndromes in man and animals appear to result from differences in target organs and in toxins associated with different

Received 22 Jan. 1996; accepted 29 Feb. 1996.

Corresponding author: Dr A. Valdivieso-Garcia (present address: Animal Diseases Research Institute, Agriculture and Agri-Food Canada, 3851 Fallowfield Road, PO Box 11300, Station H, Nepean, Ontario K2H 8P9, Canada). host species. However, these diseases appear to share a common underlying lesion of vascular endothelial damage.

SLT-IIe is closely related to SLT-II; there is $91 \%$ similarity in nucleotide and amino-acid sequences of the molecules and the A and B subunits have 94 and $84 \%$ amino-acid sequence similarity, respectively [5,6]. Like all SLTs, SLT-II and SLT-IIe have a common mechanism of action and share similar biological activities, being lethal for mice, enterotoxic in the rabbit intestine and cytotoxic for certain cell lines. However, there are differences between them in their cytotoxicity for a number of cell lines. SLT-IIe is not cytotoxic for HeLa cells [2] and Madin-Darby canine kidney (MDCK) cells, but it is more cytotoxic for Madin-Darby bovine kidney (MDBK) cells than SLT-I [7].

Glycolipid cell receptors of the globo series located at the surface have been associated with the specific binding and tissue affinity of SLTs. Globotriosylceramide $\left(\mathrm{Gb}_{3}\right)$ has been identified as the receptor for SLT-I and SLT-II. Globotetraosylceramide $\left(\mathrm{Gb}_{4}\right)$ has been shown to be the principal receptor for SLT-IIe $[8,9]$, although $\mathrm{Gb}_{3}$ may also function as an alternative receptor for SLT-IIe [9]. The affinity of the cell receptor depends upon specific binding to the 
B subunit of the toxin molecule [10]. Both $\mathrm{Gb}_{3}$ and $\mathrm{Gb}_{4}$ type receptors are found in high numbers on Vero cells; this explains their high susceptibility to SLTs [8]. The distribution of receptors varies in different tissues [11] and may also vary with age [12]. Richardson et al. [13] used a rabbit model to demonstrate that the colon, caecum and brain bound SLT-I. However, the rabbit cannot be used as an experimental model for haemolytic uraemic syndrome (HUS) or thrombotic thrombocytopenic purpura (TTP) because this species lacks $\mathrm{Gb}_{3}$ receptors in the kidney [11].

Endothelial cells appear to be the target cells in most tissues [13] and there have been several studies of the action of SLTs on primary endothelial cell cultures $[14,15]$. Local damage to colonic cells has been reported in haemorrhagic colitis and oedema disease [16]. However, it has not been established if this is a direct effect of the toxins on colonic cells or if injury to the intestinal vasculature leads to ischaemic death of colonic cells. Moyer et al. [17] reported toxic activity of Shiga toxin on human colonic cells but to our knowledge no reports have described the effect of any of the SLTs on colonic cells. Porcine endothelial cells appear to be the most relevant cell line for investigation of the effects of SLT-IIe because this cell type is most probably the target cell for this toxin in the natural disease $[16,18]$. In this study, the toxic effect of purified SLT-IIe on isolated porcine aortic endothelial cells was compared with that on bovine aortic endothelial cells and human colonic adenocarcinoma cells.

\section{Materials and methods}

\section{Cell cultures}

Procedures for the isolation and characterisation of bovine aortic endothelial (BEC-6) and porcine aortic endothelial (PEC-15) cells have been published previously [19]. PEC-8, another primary aortic endothelial cell line derived from a newborn piglet of a different litter was obtained in a similar manner. Human colonic adenocarcinoma cells, strain LS 180 (ATCC CL 187), were obtained from the American Type Culture Collection (Rockville, MD, USA). Vero cells used in this study have been described elsewhere [20].

\section{Preparation of Shiga-like toxin-Ile}

The procedures for the extraction, purification and characterisation of SLT-IIe have been described previously [21]. Briefly, E. coli strain TB1 (pCG6) containing the cloned genes for SLT-IIe [5] was used as the source of toxin. Bacterial cells grown in broth under conditions [22] that support maximal yield of toxin were collected by centrifugation. Crude toxin preparations consisting of sterile ammonium sulphateprecipitated polymyxin B cell extracts were purified by anion and cation exchange fast protein liquid chromatography (FPLC) and immunoaffinity chromatography. The purity of the toxin was determined by silver staining preparations after SDS-PAGE. Three bands corresponding to $\mathrm{A}, \mathrm{A}_{1}$ and $\mathrm{B}$ subunits of the toxin were observed. The preparation was shown to be free of endotoxin by the Limulus Amoebocyte Lysate Test (Sigma). The purified toxin was divided into small volumes and stored at $-70^{\circ} \mathrm{C}$. The tissue culture cytotoxic dose $50 \%$ (TCCD50) of SLT-IIe was determined with Vero cells before and after freezing.

\section{Cytotoxicity assay}

The neutral red cytotoxicity assay (NRA) used was a modification of the technique described previously [23]. The cell culture medium contained bovine calf serum 5\%. Briefly, aortic endothelial cells and colonic cells were allowed to grow to semi-confluency and scraped off with a rubber policeman. Trypsin was not used to separate the cells. Instead the cell suspension was passed through a pipette tip 30 times and filtered through a sterile $25-\mu \mathrm{m}$ pore nylon mesh. Cell viability was determined by the dye exclusion technique and the cell count was adjusted to $3.4 \times 10^{5}$ cells $/ \mathrm{ml}$. Two hundred- $\mu$ l volumes of medium with five-fold dilutions of SLT-IIe and $100 \mu \mathrm{l}$ of the aortic endothelial or colonic cell suspension were dispensed in the wells of a 96-well tissue culture microtitration plate (Nunc). Vero cells were treated in a similar manner, except that the cell were trypsinised. The plate was incubated at $37^{\circ} \mathrm{C}$ in a $\mathrm{CO}_{2} 5 \%$ incubator and observed every $12 \mathrm{~h}$ for 2 days. The plate was then rinsed twice with chilled cell culture medium containing EDTA $0.06 \%$, and $100 \mu \mathrm{l}$ of neutral red in PBS with EDTA $0.06 \%$ was added to each well and incubated for $20 \mathrm{~min}$ at $37^{\circ} \mathrm{C}$ in an atmosphere of $\mathrm{CO}_{2} 5 \%$ in air. The plate was rinsed three times with cell culture medium containing EDTA $0.06 \%$, and $200 \mu \mathrm{l}$ of a mixture of $0.05 \mathrm{M}$ glacial acetic acid and SDS $0.5 \%$ were added to each well. The optical density at $540 \mathrm{~nm}$ was measured in an automated spectrophotometer (Titertek Multiskan ${ }^{\mathrm{R}}$ MCC, Eflab). Each experiment was performed in triplicate.

\section{Quantification of $G b_{3}$ and $G b_{4}$}

Cell lines were grown to confluency and the total cell number was standardised to a final concentration of $5 \times 10^{6}$ cells $/ \mathrm{ml}$. The cell culture medium was removed after centrifugation and the cell pellets were kept frozen at $-70^{\circ} \mathrm{C}$ until processed. The extraction procedure and high pressure liquid chromatography (HPLC) method used have been described elsewhere [12]. Briefly, frozen cell pellets were extracted with 20 volumes of chloroform:methanol $(2: 1 \mathrm{v}: \mathrm{v})$. The residue was filtered and extracted in 10 volumes of chloroform:methanol $(1: 1)$. The extracts were pooled and partitioned against water and the lower phase was 
saponified. The extract was repartitioned and the lower phase was used for HPLC.

\section{Fluorescence activated cell sorter (FACS) analysis}

All cell lines except LS 180 were synchronised by subculture and harvesting at 2-day intervals. The LS 180 cells were synchronised by subculture at 4-day intervals. After collection, cells were exposed to purified SLT-IIe, then resuspended in mGHFC medium [19] containing sodium azide $0.1 \%$ to prevent cell modulation. The cells were kept at $4^{\circ} \mathrm{C}$ for $30 \mathrm{~min}$, then they were washed three times with PBS, $\mathrm{pH}$ 7.2, containing sodium azide $0.1 \%(\mathrm{PBS}+\mathrm{A})$. Toxin on the cell surface was labeled by adding porcine polyclonal antiserum against SLT-IIe and incubating at $4^{\circ} \mathrm{C}$ for $30 \mathrm{~min}$. Cells were washed three times in PBS $+\mathrm{A}$, then FITC-conjugated affinipure $\mathrm{F}\left(\mathrm{ab} \mathrm{b}^{\prime}\right)_{2}$ fragment goat anti-swine IgG (heavy and light chains) (Jackson ImmunoResearch Lab. Inc. distributed by BIO/CAN Scientific, Inc. Mississauga, Ontario, Canada) was added and the preparation was kept in the dark at $4^{\circ} \mathrm{C}$ for $30 \mathrm{~min}$. Cells were washed three times in PBS $+\mathrm{A}$ and analysed in the FACS model FACScan (Becton and Dickinson, Mississauga, Ontario, Canada).

\section{Determination of the TCCD50 and statistical analysis}

Toxic activity was quantified by taking the percentage cytotoxicity at each dilution of the SLT-IIe as described in the neutral red cytotoxicity assay [23] and transformed to $\log _{10}$. The TCCD50 was then calculated according to the proportionate distance procedure [24].
Analysis of variance was performed and Duncan's multiple range test was used to assess whether there were significant differences between TCCD50 values for the cell lines $(p=0.01)$.

\section{Results}

The objective of this research was to compare isolated porcine and bovine aortic endothelial cells, and human colonic adenocarcinoma cells, for their susceptibility to purified SLT-IIe. The NRA was used to assay cytotoxicity because of numerous advantages it had over the standard Vero cell cytotoxicity assay [23]. The TCCD50 values were compared with two parameters to obtain correlations: receptor binding of purified SLT-IIe to the cells assessed by FACS and concentration of $\mathrm{Gb}_{3}$ and $\mathrm{Gb}_{4}$ receptors determined by HPLC.

In the NRA, Vero cells were the most susceptible of the cell lines tested $\left(\mathrm{TCCD} 50=10^{-6.19} \mathrm{SD} 10^{-0.16}\right.$, Fig. 1). However, cytotoxic effects on the porcine aortic endothelial cells PEC-15 were evident at 12$18 \mathrm{~h}$ after exposure, whereas cytotoxicity for Vero cells was not apparent until $24-36 \mathrm{~h}$ after addition of SLT-IIe. There was a 90 -fold higher titre of toxic activity on Vero cells compared with PEC-15 $\left(\mathrm{TCCD} 50=10^{-4.32} \mathrm{SD} 10^{-0.26}\right)$. Cytotoxicity titres were 1400-fold higher on PEC-15 cells than with bovine aortic endothelial cells BEC-6 $\left(\mathrm{TCCD} 50=10^{-1.06} \mathrm{SD} 10^{-0.003}\right)$. Human colonic cells LS 180 were the least susceptible to SLT-IIe $\left(\mathrm{TCCD} 50=10^{-0.43} \mathrm{SD} 10^{-0.24}\right)$. These differences were significant ( $\mathrm{p}=0.01$; Fig. 1).

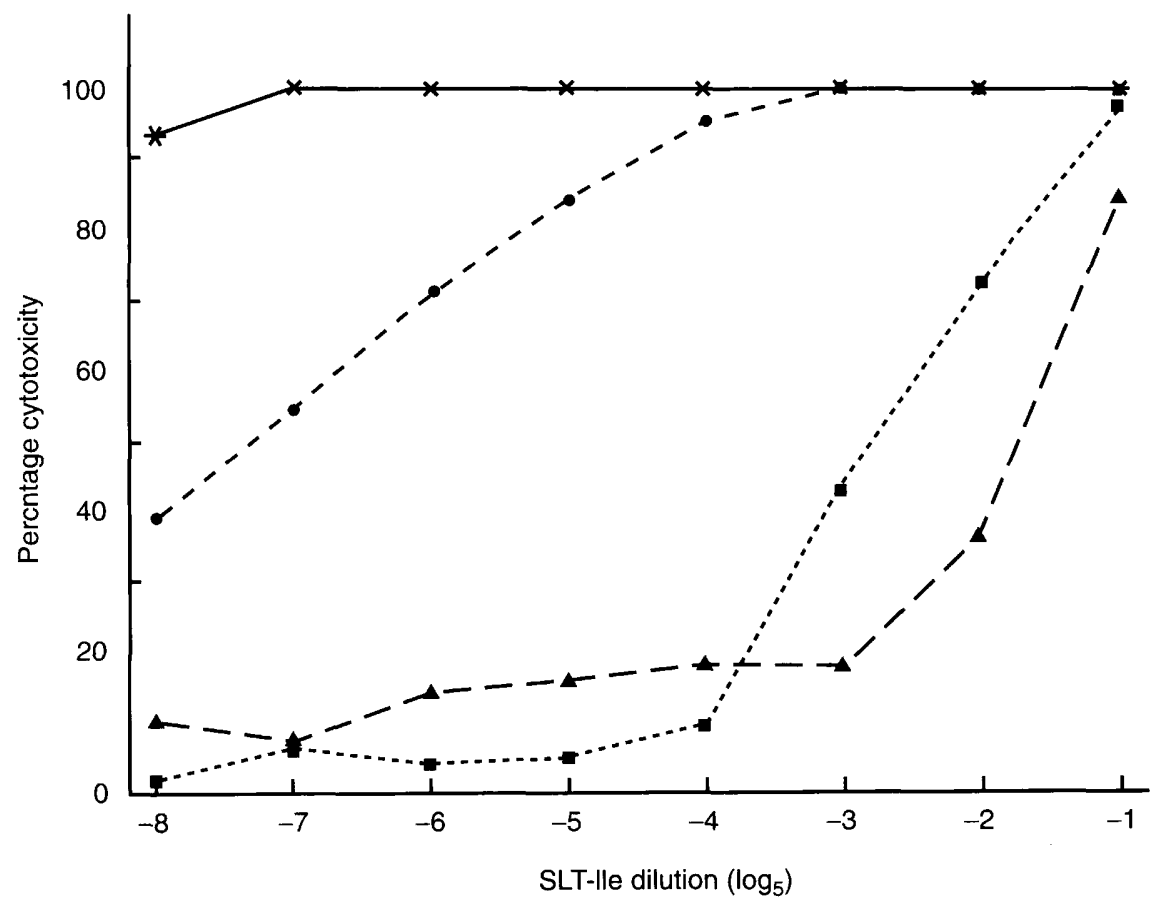

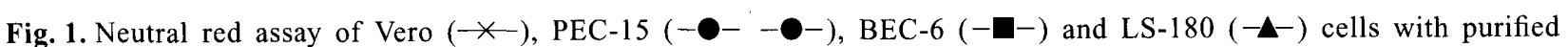
SLT-IIE. 
The other porcine aortic endothelial cell line, PEC-8, was found to be refractory to the action of SLT-IIe. Microscopic examination of PEC-15 and PEC-8 cells after exposure to SLT-IIe indicated a remarkable difference in cytotoxicity. Cultures were examined daily for 3 days. No cytotoxic reaction was observed on the first or the second day in either culture. However, on the third day changes were noted in PEC-15 but not in PEC-8. These included cytoplasmic shrinkage and nuclear condensation in the dendritic cells. Necrotic cells were frequently seen in the periphery of cell clusters.

Fig. 2 depicts the binding of SLT-IIe to different cell lines as assessed by FACS analysis. Toxin binding to Vero cells was observed as a well-defined population of cells with a high level of fluorescence at the far right of the histogram (Fig. 2a). The middle black area indicates Vero cells treated with normal porcine serum followed by goat anti-porcine $\operatorname{IgG}(\mathrm{H}$ and $\mathrm{L}$ ) conjugated with FITC (control for the polyclonal antibody), and to the far left, Vero cells treated with conjugate only (conjugate control). The same procedure was followed with PEC-15, PEC-8, BEC-6 and LS 180 cells. There was a good correlation between the FACS and cytotoxicity levels measured by the NRA in Vero cells and PEC-15 cells (Fig. 1). A small proportion of the PEC-15 population showed a positive reaction (Fig. 2b) indicating that only a limited proportion of cells expressed $\mathrm{Gb}_{4}$. With PEC-8 (Fig. 2c) and the bovine aortic endothelial cells BEC-6 (Fig. $2 \mathrm{~d})$ there was no specific binding. A distinct profile was observed with LS 180 cells (Fig. 2e); this was probably due to non-specific binding of SLT-IIe on a proportion of the cell population because LS 180 cells were the least susceptible to SLT-IIe in the NRA and $\mathrm{Gb}_{4}$ was absent as assessed by HPLC.

The content of $\mathrm{Gb}_{4}$ was greatest in Vero cells, followed by PEC-15 cells and PEC-8 cells (Fig. 3). BEC-6 cells, which are considerably less susceptible to SLT-IIe than PEC-15 cells (Fig. 1) and LS 180 cells did not have detectable levels of $\mathrm{Gb}_{4}$ (Fig. 3).

\section{Discussion}

In this study, aortic endothelial cells minimally exposed to trypsin were used to compare the susceptibility to SLT-IIe of cells or porcine and bovine origins. A human intestinal cell line and Vero cells were used as other bases for comparison of cytotoxicity. Cells which have not been exposed to proteolytic enzymes retain the natural biochemical integrity of the glycocalyx. Proteolytic enzymes have a deleterious effect on the longevity of the cell line and some cell receptors, but not glycosphingolipid receptors, may be lost during trypsinisation [25]. Cytotoxicity assays require the number of cells to be standardised. Therefore, the

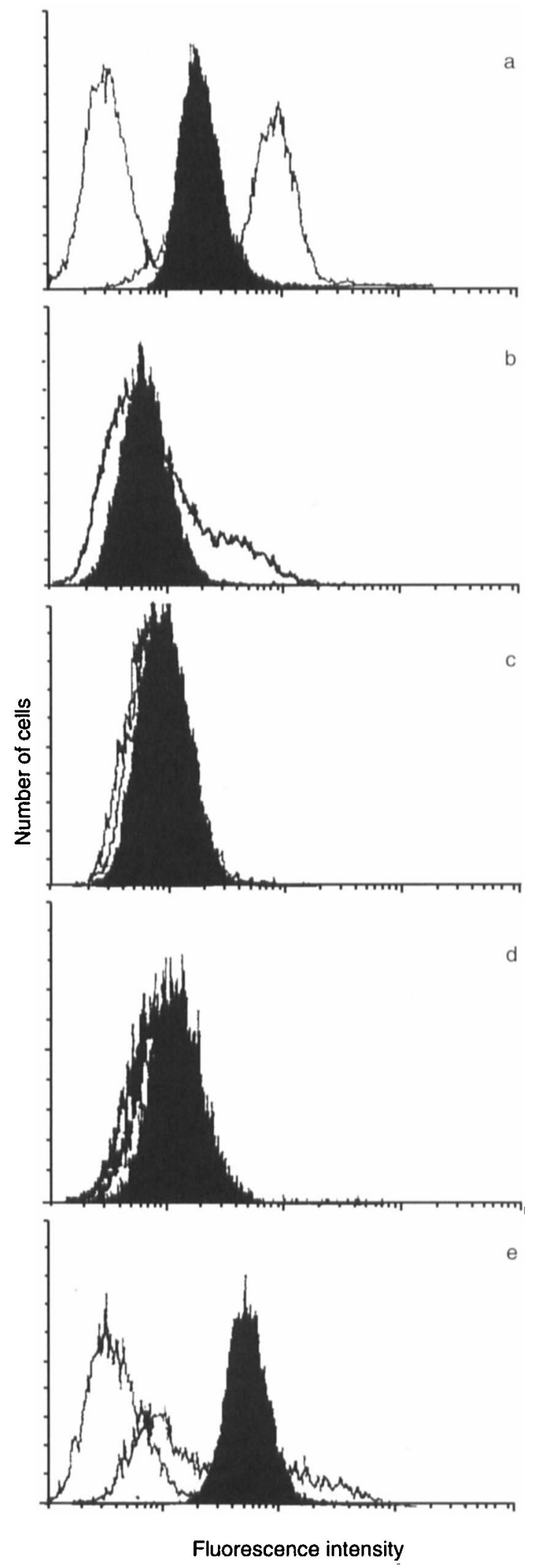

Fig. 2. FACS analysis of SLT-IIe binding to cells. Cell suspensions were exposed to purified SLT-IIe and porcine polyclonal anti-SLT-IIe was applied, followed by goat anti-porcine IgG ( $\mathrm{H}$ and $\mathrm{L}$ ) labelled with FITC (far right). Controls included cells treated with normal porcine serum and FITC-conjugated goat anti-porcine IgG ( $\mathrm{H}$ and $\mathrm{L})$ (black area) and cells treated with conjugate only (far left). a, Vero cells; b, PEC-15; c, PEC-8; d, BEC-6; e, LS 180. 


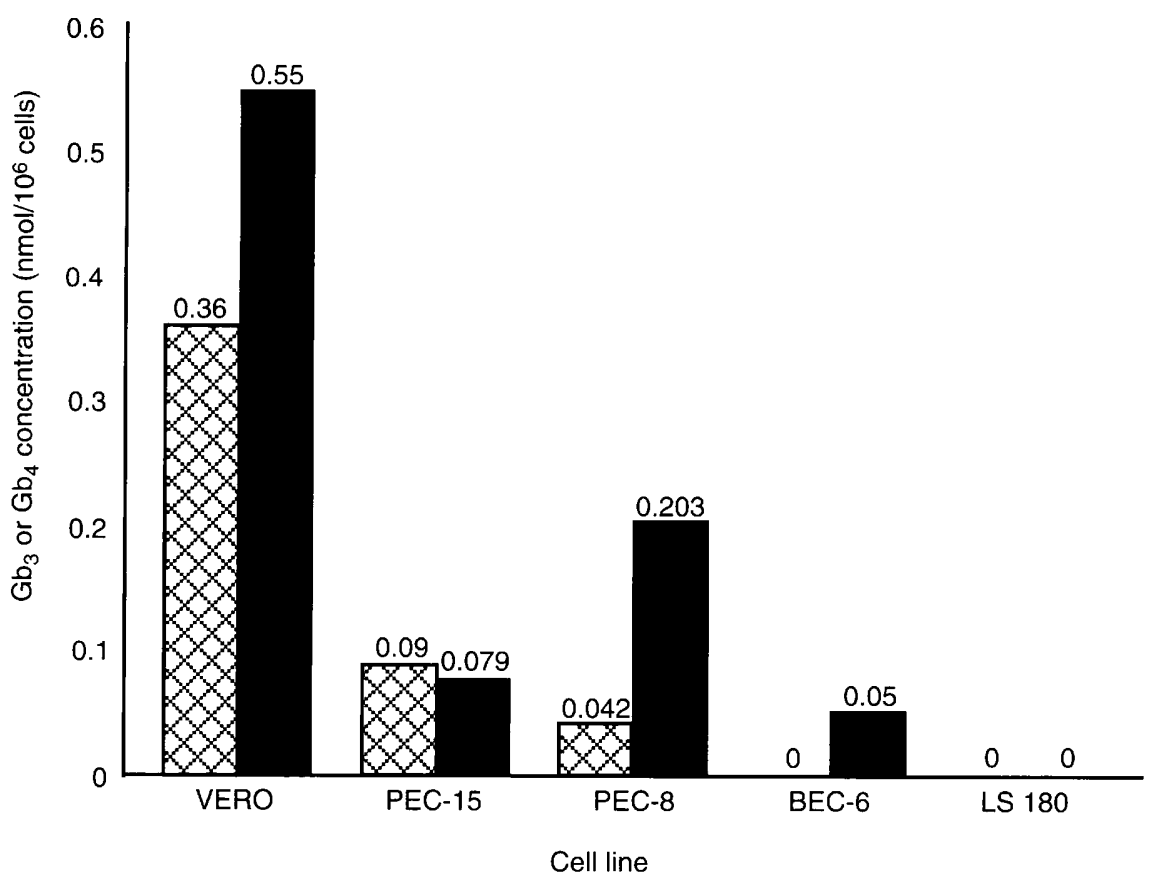

Fig. 3. Concentration of $\mathrm{Gb}_{3}(\boldsymbol{\square})$ and $\mathrm{Gb}_{4}$ ( Cell lines were grown to confluency and total cell number was standardised to $5 \times 10^{6}$ cells final concentration, and glycolipids were extracted and quantified by HPLC.

cultures were exposed briefly to trypsin (30 s) to avoid cell aggregations and facilitate the procedure.

Vero cells were the most susceptible to SLT-IIe followed, in decreasing susceptibility, by porcine aortic endothelial cells PEC-15, bovine aortic endothelial cells BEC- 6 and human colonic adenocarcinoma cells LS 180. Cytotoxicity for porcine endothelial cells PEC-8 was not determined. The relationship between cell susceptibility and content of the glycolipid receptor $\mathrm{Gb}_{4}$ in all cell lines was clearly demonstrated. Although the total concentration of receptors $\mathrm{Gb}_{3}$ and $\mathrm{Gb}_{4}$ in Vero cells was $0.91 \mathrm{nmol} / 10^{6}$ cells, more than half was $\mathrm{Gb}_{3}\left(0.55 \mathrm{nmol} / 10^{6}\right.$ cells $)$. SLT-IIe binding to $\mathrm{Gb}_{3}$ has been reported, but the binding affinity is low $\left(\mathrm{k}_{\mathrm{d}}=1.36 \times 10^{-7} \mathrm{M}\right)$ [26] compared with the binding affinity for $\mathrm{Gb}_{4}\left(\mathrm{k}_{\mathrm{d}}=1.48 \times 10^{-8} \mathrm{M}\right.$ [26]. The lower binding affinity of SLT-IIe for $\mathrm{Gb}_{3}$ may explain the inefficient biological activity as evidenced by the partial neutralisation of SLT-IIe by $\mathrm{Gb}_{3}$, the lower cytotoxicity levels and the prolonged time required for removal of cytotoxicity with liposomes coated with $\mathrm{Gb}_{3}[8]$.

Keusch et al. [9] reported recently that $\mathrm{Gb}_{3}$ could also function as a receptor for SLT-IIe in Vero cells and HeLa cells. In the present studies the $\mathrm{Gb}_{3}$ content of porcine and bovine endothelial cells did not mediate cytotoxicity by SLT-Ile, but cytotoxicity was in direct proportion to the $\mathrm{Gb}_{4}$ content (Figs. 1 and 3). By FACS analysis (Fig. 2) $\mathrm{Gb}_{3}$ was not able to bind SLTIIe in PEC- 8 cells in which the $\mathrm{Gb}_{3}$ content was almost three times higher than PEC-15 cells. Furthermore, binding of SLT-IIe to BEC-6 cells in which only $\mathrm{Gb}_{3}$ was detected was not found. Binding was observed only in Vero cells and PEC-15 cells that showed the highest $\mathrm{Gb}_{4}$ content of the cell lines examined (Figs. 2 and 3). This indicates that although $\mathrm{Gb}_{3}$ is present in PEC-8 cells in a higher concentration than PEC- 15 cells, and in BEC-6 cells, it may be found in a different configuration at the cell surface and be unable to bind SLT-IIe. It is most likely that $\mathrm{Gb}_{3}$ was exposed in PEC-8 cells as all tissue cultures were treated mildly with trypsin and this procedure should have made $\mathrm{Gb}_{3}$ more available at the cell surface [27].

Because LS 180 cells appeared to bind toxin although they lacked the specific receptor, the binding was probably non-specific. The reason for this may be the negatively charged highly sialated glycoproteins characteristic of colonic carcinoma cells [28]. This suggests that SLT-IIe may be capable of non-specific binding to the gastrointestinal mucosa. Specific receptors for SLT-IIe appear to be present in the jejunum and ileum of pigs (Waddell and Gyles, unpublished observations) and specific binding to intestinal epithelial cells can, therefore, be expected to occur in the natural infection. In newborn pigs, oral infection with strains of human VTEC of serotype O157:H7, which produce SLT-I or SLT-II or both, results in colonisation of the colon, signs of verotoxaemia and death [29]. If the pigs are challenged at 1-2 days of age, there is colonisation of the colon but no evidence of verotoxaemia. These data suggest that absorption of toxin from the colon occurred only in a pre-closure environment.

For the NRA and the FACS analysis only lowpassaged and subconfluent PEC-15 cells were used. 
High-passaged PEC-15 cells became refractory to killing and binding of SLT-IIe whereas PEC-8 cells at low or high passage were not susceptible. This may relate to change in the distribution and availability of $\mathrm{Gb}_{4}$, because PEC-15 cells grown to $75 \%$ subconfluency and treated with SLT-IIe produced unequivocal morphological changes, whereas confluent monolayers did not react to the presence of SLT-IIe. This can be explained by the observation that quiescent cultures arrest important eukaryotic functions, particularly in receptor-mediated endocytosis, that occur when contact inhibition is established in the monolayer [30]. Kavi et al. [14] described a similar situation with porcine aortic endothelial cells but they did not identify the type of verotoxin they used. They found that only actively dividing cells were susceptible to the verotoxin. Obrig et al. [15] reported a similar observation with SLT-I and human umbilical vein endothelial cells (HUVEC). Pudymaitis and Lingwood have demonstrated that cytotoxicity of SLT-I is a function of the cell growth in which cyclic turnover and exposure of $\mathrm{Gb}_{3}$ seem to be critical for the cytotoxicity of SLT-I [31].

Although PEC-8 cells were isolated by a procedure that was identical to that used with PEC-15, the PEC8 cells were refractory to the toxic action of SLT-IIe. Both cell lines originated from the same farm but came from different litters, and were identified as endothelial cells by specific cell markers [19]. The difference in cytotoxicity was correlated with differences in receptor concentration measured by HPLC. The finding of such remarkable variability suggests that cells from more than one source should be tested if one preparation is found to be refractory. The ready susceptibility of pigs from many sources to intravenously administered SLT-IIe $[16,18]$ also suggests that absence of vascular endothelial $\mathrm{Gb}_{4}$ does not occur frequently in nature.

However, it should be noted, that the susceptibility of only some tissues to the effects of SLT-IIe $[16,18]$ is not only a function of $\mathrm{Gb}_{4}$ concentration but also of blood flow [32]. Boyd et al. determined the concentrations of $\mathrm{Gb}_{3}$ and $\mathrm{Gb}_{4}$ in a number of pig tissues (but not from vasculature of the tissues), and found $\mathrm{Gb}_{4}$ to be particularly high in red blood cells. This correlated with extensive red blood cell binding whereas VT1 and GT3 showed minimal binding to red blood cells. Therefore, it was concluded that red blood cells deliver SLT-IIe to target organ receptors [32]. It would be desirable to investigate porcine endothelial cells from a number of the target tissues because receptors on endothelial cells may be functional and may modulate interaction with other cell messengers. Recent investigations have shown that HUVEC and human renal (glomerular) microvascular endothelial cells (HRMEC) respond very differently to nanomolar concentrations of Shiga toxin in the presence of LPS, tumour necrosis factor- $\alpha$ and interleukin-1 $\beta$ [33], indicating the significance of the anatomical origin of the endothelial cell. HRMECs are the putative target cells in HUS, and the most striking difference between the two cell types is the concentration of $\mathrm{Gb}_{3}$, the specific functional receptor for SLT-I and SLT-II. HRMECs express $\mathrm{Gb}_{3}$ at concentrations that are 50 times higher than those found in HUVEC [33] and that seems to be the determining factor in the clinical presentation of HUS.

We thank Monique Parenteau and Marilyn Davis for running the FACScan. A. V.-G. (a visiting fellow in the Canadian Government Laboratories Program) was supported by a grant from the Ministry of State for Science and Technology.

\section{References}

1. Gyles CL. Escherichia coli cytotoxins and enterotoxins. Can J Microbiol 1992; 38: 734-746.

2. Marques LRM, Peiris JSM, Cryz SJ, O'Brien AD. Escherichia coli strains isolated from pigs with edema disease produce a variant of Shiga-like toxin II. FEMS Microbiol Lett 1987; 44: 33-38.

3. Meyer T, Karch H. Genes coding for Shiga-like toxin and heatstabile enterotoxin in porcine strains of Escherichia coli. FEMS Microbiol Lett 1989; 58: 115-120.

4. Strockbine NA, Marques LRM, Newland JW, Smith HW, Holmes RK, O'Brien AD. Two toxin-converting phages from Escherichia coli 0157:H7 strain 933 encode antigenically distinct toxins with similar biologic activities. Infect Immun 1986; 53: $135-140$.

5. Gyles CL, DeGrandis SA, MacKenzie C, Brunton JL. Cloning and nucleotide sequence analysis of the genes determining verocytotoxin production in a porcine edema disease isolate of Escherichia coli. Microb Pathog 1988; 5: 419-426.

6. Weinstein DL, Jackson MP, Samuel JE, Holmes RK, O'Brien AD. Cloning and sequencing of a Shiga-like toxin type II variant from an Escherichia coli strain responsible for edema disease of swine. J Bacteriol 1988; 170: 4223-4230.

7. Gannon VPJ, Gyles CL. Characteristics of the Shiga-like toxin produced by Escherichia coli associated with porcine edema disease. Vet Microbiol 1990; 24: 89-100.

8. DeGrandis S, Law H, Brunton J, Gyles C, Lingwood CA. Globotetraosylceramide is recognized by the pig edema disease toxin. J Biol Chem 1989; 264: 12520-12525.

9. Keusch GT, Jacewicz M, Acheson DWK, Donohue-Rolfe A, Kane AV, McCluer RH. Globotriaosylceramide, $\mathrm{Gb}_{3}$, is an alternative functional receptor for Shiga-like toxin 2e. Infect Immun 1995; 63: 1138-1141.

10. Head SC, Karmali MA, Lingwood CA. Preparation of VT1 and VT2 hybrid toxins from their purified dissociated subunits. $J$ Biol Chem 1991; 266: 3617-3621.

11. Zoja C, Corna D, Farina C et al. 'Verotoxin glycoplipid receptors determine the localization of microangiopathic process in rabbits given verotoxin-1. J Lab Clin Med 1992; 120: $229-238$.

12. Boyd B, Lingwood C. Verotoxin receptor glycolipid in human renal tissue. Nephron 1989; 51: 207-210.

13. Richardson SE, Rotman TA, Jay V et al. Experimental verocytotoxemia in rabbits. Infect Immun 1992; 60: 4154 4167.

14. Kavi J, Chant I, Maris M, Rose PE. Cytopathic effect of verotoxin on endothelial cells. Lancet 1987; 2: 1035.

15. Obrig TG, Del Vecchio PJ, Karmali MA, Petric M, Moran TP, Judge TK. Pathogenesis of haemolytic uraemic syndrome. Lancet 1987; 2: 687.

16. Gannon VPJ, Gyles CL, Wilcock BP. Effects of Escherichia coli Shiga-like toxins (verotoxins) in pigs. Can J Vet Res 1989; 53: 306-312.

17. Moyer MP, Dixon PS, Rothman SW, Brown JE. Cytotoxicity of Shiga toxin for primary cultures of human colonic and ileal epithelial cells. Infect Immun 1987; 55: 1533-1535.

18. MacLeod DL, Gyles CL, Wilcock BP. Reproduction of edema disease of swine with purified Shiga-like toxin II variant. Vet Pathol 1991; 28: 66-73. 
19. Valdivieso-Garcia A, Rosendal S, Allen OB, Thompson CM, Watson S. Cytotoxicity of Mycoplasma mycoides subspecies mycoides for cultured endothelial cells. Int $J$ Med Microbiol 1989; 272: 202-209.

20. Gannon VPJ, Gyles CL, Friendship RW. Characteristics of verotoxigenic Escherichia coli from pigs. Can J Vet Res 1988; 52: $331-337$.

21. MacLeod DL, Gyles CL. Purification and characterization of an Escherichia coli Shiga-like toxin II variant. Infect Immun 1990; 58: 1232-1239.

22. MacLeod DL, Gyles CL. Effects of culture conditions on yield of Shiga-like toxin-IIv from Escherichia coli. Can J Microbiol 1989; 35: 623-629.

23. Valdivieso-Garcia A, Clarke RC, Rahn K, Durette A, MacLeod DL, Gyles CL. Neutral red assay for measurement of quantitative vero cell cytotoxicity. Appl Environ Microbiol 1993; 59: 1981-1983.

24. Rovozzo GC, Burke CN. A manual of basic virological techniques. Englewood Cliffs, NJ, Prentice-Hall Inc. 1973: 87-93.

25. Ryan US, White LA, Lopez M, Ryan JW. Use of microcarriers to isolate and culture pulmonary microvascular endothelium. Tissue Cell 1982; 14: 597-606

26. Tyrrell GJ, Ramotar K, Toye B, Boyd B, Lingwood CA, Brunton JL. Alteration of the carbohydrate binding specificity of verotoxins from Gal $\alpha 1-4 \mathrm{Gal}$ to GalNAc $\beta 1-3 \mathrm{Gal} \alpha 1-4 \mathrm{Gal}$ and vice versa by site-directed mutagenesis of the binding subunit. Proc Natl Acad Sci USA 1992; 89: 524-528.

27. Grant CWM. Cell surface structural implications of some experiments with isolated glycolipids and glycoproteins. Can $J$ Biochem Cell Biol 1984; 62: 1151-1157.

28. Forstner G, Sherman P, Forstner J. Mucus: function and structure, In: Boedeker EC (ed) Attachment of organisms to the gut mucosa, vol II. Boca Raton, FL, CRC Press Inc. 1984: 14-20.

29. Francis DH, Moxley DA, Andraos CY. Edema disease-like brain lesions in gnotobiotic piglets infected with Escherichia coli serotype 0157:H7. Infect Immun 1989; 57: 1339-1342.

30. Wyrick PB, Choong J, Davis $\mathrm{CH}$ et al. Entry of genital Chlamydia trachomatis into polarized human epithelial cells. Infect Immun 1989; 57: 2378-2389.

31. Pudymaitis A, Lingwood CA. Susceptibility to verotoxin as a function of the cell cycle. $J$ Cell Physiol 1992; 150: 632-639.

32. Boyd B, Tyrrell G, Maloney M, Gyles C, Brunton J, Lingwood C. Alteration of the glycolipid binding specificity of the pig edema toxin from globotetraosyl to globotriaosyl ceramide alters in vivo tissue targetting and results in a verotoxin 1-like disease in pigs. $J$ Exp Med 1993; 177: 1745-1753.

33. Orbrig TG, Louise CB, Lingwood CA, Boyd B, BarleyMaloney L, Daniel TO. Endothelial heterogeneity in Shiga toxin receptors and responses. J Biol Chem 1993; 268: 15484 15488 . 